\title{
3 Gandhian perception of Socio-economic Development
}

Ashis Kumar Sinha, Journalist, Research Scholar, Jharkhand. India. email:mail4daily@gmail.com

\begin{abstract}
Mahatma Gandhi has his own vision on the development strategy for India. Though he was not an economist he has given economic vision. If his vision or thoughts implemented, it could solve many socioeconomic problems in the country. His basic aim was to have an inclusive growth of the society that includes human development along with socio-economic and political development. His thoughts are holistic and multidimensional for the formation of a non-violent society. Gandhi's vision and thoughts are very precisely summarized in 'Hind Swaraj', which was published in 1909; which intended moral, social and political regeneration of the country. His economic visions thoughts have a great impact on the Indian economy. He proposed very constructive economic ideas; emphasized on cottage and small scale industries which have significant importance for the development of the Scio-economic condition of the common people and also adopted the principle of 'Swadeshi'. But now in the age of globalization, large scale industries coming with rampant use of automation are responsible for several socio-economic problems in our country. Therefore, the objective of this paper is analysing the present economic scenario from the Gandhian perspective of economic development or the Gandhian concept of socio-economic development.
\end{abstract}

Conclusion: Mahatma Gandhi's economic ideas are very practical, if implemented, our country could get relief from several socio-economic problems. Our country or government should emphasize his policy which especially represents 'Swadeshi' and works for common people. Presently, our country is facing a number of socio-economic problems on account of large scale industries and computerization or automation. In such a scenario, there is an urgent need to rethink over Gandhi's economic principles. Small scale industries play a key role in our economic development. Such industries usually used labor and have a high potential for employment generation. Gandhi's view was that industrialism (which uses capitalism) is based on the exploitation of the people. 
(C) Ashis Kumar Sinha.

Key words: Mahatma Gandhi, socio-economic development, Swadeshi, Gandhian thought.

\section{Introduction}

Gandhiji played a vital role in the national movement. He engaged in non-violence and peaceful struggle against British rule; encouraged village industries to improve the economic condition of the country. His economic vision is full of a rich understanding of economic dynamics and processes as well as of human and social realism. For Gandhiji, the economy was meaningful to such an extent that it opened out the possibility of happiness for all.

Nuti Namita, Assistant Professor (History), Sri Venkateswara College Delhi University writes, Gandhi had an inherent distrust of modernization based on the western concept of development parameters. He was critical of large-scale industrialisation, not only because it created havoc in the environment, but also because it led to extensive unemployment. Gandhi found the modern civilisations, for all its achievements, fundamentally rooted in the pursuit of ever-increasing wants with its harmful consequences. It contributed to inequality and non-harmonious relations amongst members of society. "Neither railways nor hospital are a test of a high or pure civilization. At best they are a necessary evil. Neither adds one inch to the moral stature of a nation."

According to the Gandhi's thought cottage industries not only helped in maintaining the continuity of traditional crafts but also generated employment opportunities for many. Gandhi was very particular about the unpleasant results of modernization on the environment. According to him, nature provided enough for everyone's needs but not for everyone's greed. 'Be the change you want to see in this world,' he said. Gandhi urged the proponents of rapid mechanization of agriculture that trading in soil fertility for the sake of quick returns would prove to be disastrous.

Ghosh (2007: 213) writes the basic objectives of the Gandhian scheme of holistic development includes (1) Human development for capability expansion including moral development

(2) Development in a balanced way through manual and intellectual labour that is development of body, mind and soul,

(3) Development with social justice, rights and freedom. 
(C) Ashis Kumar Sinha.

(4) Accomplishment of self sufficiency and self reliance through rural development,

(5) Generation of additional income and employment to reduce poverty

Gandhiji apprehend that human development is not just material or economic; it should be able to inspire the values of equality, liberty as well as dignity and must provide courage to a person to protest against injustice. He stressed on a self-sufficient economy which includes community based economics, self sufficiency, handicrafts, rural development and use of low capital on suitable technology.

According to Gandhi nature provides just enough (not more) for our daily needs. He opposes exploitation, ruthless drive for economic abundance and personal exaggeration, enormous technological progress, stern competitions, uncontrolled consumerism and concentration of wealth and power. In his opinion, greediness is harmful to social good and political emancipation without economic equality is hollow. For him, economics stands for social justice. (Harijan, October 9, 1937)

He stressed decentralized self-dependent units bound together by the bonds of mutual cooperation and interdependence. For him, the development of the individual and the development of society are tangled. Sarvodaya was his ultimate goal which spells the development of all, in all aspects of life. The concept of Sarvodaya assumes the principle of justice it generates movements for changes, outward as well as inward and strives for egalitarian social order based on truth, nonviolence and purity of means.

Gandhi never wants to compromise at the value of the liberty of the people, equality and social justice, his principle of nonviolence was the rule of his life. He dreams for a prosperous India where "all interests not in conflict with the interests of the dumb millions are going to be scrupulously respected, whether indigenous or foreign." (Young India, September 10,1931).

Gandhi's basic aim was to possess an inclusive development of the society that included human development along side socio-economic and political development. Gandhian programme is holistic and multidimensional. His objective was creation of a non-violent society. He visualizes for a healthy society which might be supported harmony and dialogues, where ideas of equality and justice are translated within the lives of all. 
Remarking on the social nature of human Gandhi writes, "If it is his privilege to be independent it is equally his duty to be independent.... It will be possible to reconstruct our villages in order that villages collectively, not villagers individually, will become self-contained." (Young India, April 25, 1929).

Gandhi believes within the unity of life and democratic values in life. Consistent with him, life can not be divided into sphere-like social, political, economic, moral and non-secular. If one a part of the society suffers, all parts suffer.

J. B. Kripalani and Dada Dharmadhikari (Thakkar and Mehta, 2011), J. B. Kriplani points out that it is not remarkable to have saints among us - saints who meditate for salvation and who are concerned with the uplift of the soul. It is their contribution to the evolution of human history in an indirect way but Gandhi was concerned through a direct way. Social involvement is very important to him. Gandhi visualized a society of diverse people based on mutual understanding, mutual cooperation and mutual respect. He wanted freedom and equality for all. Gandhi goes above the barriers of religion, rituals, caste, class and colour.

Dada Dharmadhikari points out that Gandhi had 'no business other than life, an integrated life'. He never ran far away from any situation, he faced it. His concept of life was all comprehensive; for him nothing was separate and everything was harmonized. He added a social dimension to morality that was unique. He practiced what he preached and did everything possible to spot himself with the commoner, ordinary or suffering man. When India became independent, he was not in the capital to celebrate but was with the riot-stricken people. Gandhi maintains that wealth is to be used judiciously, governed by the principle of 'each according to his need'; and therefore the emergence of inequality has got be curbed in the least levels. All amassing or hoarding of wealth, above and beyond one's legitimate requirement is theft. (Harijan, August 11, 1946).

His concept of the social use of wealth against the prevailing ethos of consumerism demands our serious attention. Values of 'truth' 'non-violence' and 'non-accumulation of wealth' are to be cherished for the very survival of the society, where the weakest has an equivalent right as the strongest. 


\section{Significance of Gandhian Thoughts:}

The great economic ideology of Gandhi enhanced the development of rural areas and minorities by giving them equal and sustainable earnings, therefore question presents itself: What's his relevance of economic thought of Gandhi ji today for Indian economy. Globalization has been playing a vital role in Indian economy. The economy of India is currently the world's fourth largest in terms of real GDP (Gross Domestic Product) after the USA, China and Japan. It has registered ninth position in terms of GDP (Gross Domestic Product) and fourth position in terms of PPP (Purchasing Power Parity) and recorded highest constant growth rates within the 21 st century. It has accounted for an amazing rate of growth in 2011-12, which is estimated at 7.1 per cent (Economic Survey 2011-12).

In the Year of 1947, when India achieved independence from British rule, it had faced stagnation in economy and was caught up in a vicious circle of poverty. Then Indian government took a policy of 'laissez fair', which was expressed by Jawaharlal Nehru. India focused on the import substitution policy. Due to this India has give stress on development of industrialisation in large scale. As a result new and foreign industries are coming to Indian market which enhances India's growth. But this type of progress is on sided because the profits goes to only entrepreneurs and people who are benefitted from these reforms and globalization are entrepreneurs and belonging to business class.

Therefore the gap between the rich and poor has increased. Most of the private enterprise is established in urban and large cities in order that villages are totally ignored by the industrialist who would lead them demoralize. On the other hand India is a country of villages where most of the people lives (Nachane, 2007).

However, the production on large scale would create conflicts between labour and capital. Here capital takes whip hand over labour. Such conflicts may not occur within the case of rural industries. Rural industries are the symbols of unity and equality. In India large-scale industries are concentrated in a few big cities and in rural areas there is no big industry like khadi, handlooms, sericulture and handicrafts. The small-scale and cottage industries would give a deliberate place in our planned economy towards the fulfilment of the socio economic objectives of Gandhi's particularly in achieving equitable 


\section{(C) Ashis Kumar Sinha.}

and sustainable growth. So there is need to move back to Gandhian economic ideology who was always in fever of Swadesi and self- reliance of villages. If all the land and resources that's available was fully utilized, it might definitely fulfill the requirements of all. If we should try to improve villagers workmanship and buy their products in spite of imported products or even articles produced in big cities, big factories. In other words, we should induce the creative talent of the villager and develop their indigenous market in the present 21 st century.

Gandhi's term true 'Swadeshi' consists in enhancing and stimulating cottage and small industries. It also provides opportunities to the original talent and imagination of the people. It can generate employment for Indian youth in the country that is in search of job. so India should adopted the economic mode and idea of Gandhiji which completely favourable in the present Indian economy because India's balance of payment is unfavorable because India export more from other countries rather than produce in our country by using labour intensive technology. The products which are imported by India such a high technology based. on the other hand, if India should follow his ideas of self sufficiency and 'Swadesi' India never face these types of problems. So, India must need to go back Gandhian economic ideology.

\section{Conclusion}

Presently, India is facing many socio-economic problems on account of large scale industries and computerization or automation. So in the present circumstances, there is an urgent need to rethink over Gandhi's economic ideology. Small scale industries play a key role in our economy for its development. These industries are basically using labour intensive and high potential for employment generation. Gandhi's thought that industrialism which uses capital intensive technique is based on the exploitation of individuals. As a result, most of the people would be suffered from this sort of mechanism. So India should emphasis on the policy of Gandhi ji which especially represent the 'Swadeshi' and work for common people.

\section{References:}

https://www.mkgandhi.org/articles/gandhian-perspective-of-development.html

http://indiabudget.nic.in/survey.asp ; Economic Survey (2012). 
The Researchers' - Volume VI, Issue I, 10 March-2020

International Research Journal (Double-blind peer-reviewed)

Date of Acceptance : 12 November 2019
ISSN : 2455-1503

Impact Factor - 3.635

DOI - 10.21276/tr.2020.6.1.AN3

(C) Ashis Kumar Sinha.

Namita Nuti; https://www.freepressjournal.in/health/gandhijis-idea-of-development

Kaur Amandeep \& Singh Bhupinder (2015); "Relevance of Gandhian Economic Thought: An Appraisal"; International Journal of Advanced Research in Management and Social Sciences; ISSN: 2278-6236; Volume 4(1); pp 115-123. https://www.researchgate.net

Ishii, K. (1994); The Socio-Economic Philosophy of Mahatma Gandhi: with a Particular Focus on his Theory of Trusteeship; The Economic Review. 154(1).pp:72-91.

Bhuimali, A. (2014); "Relevance of M. K. Gandhi's Ideal of Self-Sufficient Village Economy in the 21st Century"; Articles on Gandhi. Sarvodaya. Vol1(5).

Ghosh, B N; Gandhian Political Economy: Principles, Practice and Policy, Ashgate Publishing Ltd., Aldershot, Hampshire, UK, 2007.

Nayak, P. (2005); "Gandhian Economics is Relevant”.

Dodh, P. (2012); "Impacts of Globalization on Social Inclusion: A Comparative Analysis to Gandhian Economic Philosophy"; IJPSS Volume 2(5); pp: 287-297.

Kurian, M. (2013); “Globalisation and India's Economic Identity: An Overview”; Mainstream, VOL XLVI (32). pp 1-6.

Koshal, R. K. and Koshal, M. (1973); "Gandhian Economic Philosophy"; American Journal of Economics and Sociology, Vol. 32, No. 2, April, 1973, pp. 191-209. 